\title{
IMPROVING FOREST-BASED LIVELIHOODS THROUGH INTEGRATED CLIMATE CHANGE ADAPTATION PLANNING
}

\author{
Pratima Shrestha (Nepal) \\ Dev Raj Gautam (Nepal)
}

\begin{abstract}
Forest-based livelihoods are ruthlessly affected by climate change and other non-climatic stressors. Forests as one of the precious natural assets available in the Chitwan Annapurna area is an appropriate sector to address community and ecosystem vulnerability through adaptation works like plantation, protecting biophysical environment against hazards like landslide, floods, and water scarcity. In Nepal, Community Forest Users Groups with legal entity serves as grassroot organizations in preparation of community based adaptation plan of action (CAPA). Hariyo Ban Program, have facilitated in preparation of community based adaptation plans in remote, vulnerable and marginalized communities of different places of Gandaki river basin. The result shows community perception towards climatic and non climatic stresses and its impacts in forest based livelihoods. Climate change, its variability and extreme events have mystified people's livelihood and forced them to further suffering. Preparation and implementation of adaptation plans has provided a ray of hope towards addressing adverse impact of climate change. Till date, 142 community adaptation plans are prepared following a methodology on integrated community adaptation planning. Adaptation planning has let community know about the prevailing threats and vulnerabilities in their communities and helped to identify adaptation measures to reduce those threats and vulnerabilities, resulting in improved livelihoods.
\end{abstract}

KEYWORDS: Community forest, forest based livelihood, climate change adaptation, Chitwan Annapurna landscape

\section{INTRODUCTION}

In 1979, World Meteorological Organization, reported climate change as a serious problem through the First World Climate Conference ${ }^{1}$. Climate change is emerging as great concern at global and local level. Worldwide, it has posed various threats to people, biodiversity and economies at different scale. The recently published Fifth Assessment Report (AR5) by Intergovernmental Panel on Climate Change (IPCC, 2013) confirmed that human activities are more responsible for global warming. It also states that many observed impacts are happening more quickly than previously predicted, and climate change is creating more frequent and more intense extreme weather events. People who are relying on natural resources for their subsistence living are hit the hardest from these cli- 


\section{Crossing the Border: International Journal of Interdisciplinary Studies}

mate change, variability and extreme weather events.

In Nepal, majority of rural communities depend on forest based livelihoods. Poor people derive different ecosystems services to sustain their livelihoods. So these forest based resources are very much critical to the human development of Nepal. Nepal's forestry sector is one of the important sector which supplies about 80 percent of cooking energy (Ghimire, 1999), and provides 1.36 million fulltime jobs per year in fuel-wood and fodder collection (CBS, 1999). Thus forest resources are of particular concern in the context of current climate change in order to protect the resources in context of vulnerabilities. Maplecroft has identified Nepal in fourth position, on the basis of calculated vulnerability of 170 countries to the impacts of climate change over the next 30 years $^{2}$. In addition, Nepal's National Adaptation Plan of Action, 2010 reported that many sectors - agriculture, forestry, water and energy, public health, urban development, tourism and industries are becoming more affected in Nepal due to climate change impacts.

Climate change impacts are being addressed through the ways of mitigation and adaptation. Mitigation involves reducing emissions of greenhouse gases or increase carbon sequestration from the atmosphere. Adaptation in other hand is adjusting to the natural or human system by learning to cope with temperature increases, floods, and other climatic risks and hazards associated with climate change (Reid and Huq, 2007). Adaptation actions have consequences for mitigation and so do mitigation action support adaptation. (Klein, R.J.T. et al, 2007) And adaptation is already a necessity as people's lives and livelihoods face an increasing burden of broader shocks and stresses (CARE, 2009).

Thus, the overall people's livelihoods and national economy is negatively impacted. The projected socioeconomic impacts of climate change presents significant challenges for affected communities, particularly the poor and forest-dependent, who are already vulnerable to climate variability, changing political and economic circumstances, and social exclusion. As a result, livelihoods of rural and poor communities are highly vulnerable to climate changes (Info resources, 2004) and at risk to lose the livelihood options.

Integrated community and ecosystem based adaptation planning is one of the important way to minimize the impacts of climatic and non climatic stresses on livelihood and enhance the resilience capacity of vulnerable people and restore ecosystem. Hariyo Ban Program ${ }^{3}$ acknowledges the integrated adaptation and has been conducting climate vulnerability assessment and preparing integrated adaptation planning within the working areas in two important landscapes: Terai Arc Landscape (TAL) stretched in low-land Terai between the Bagmati River in the east and Maharani in the west including Curia range, and north-south Chitwan-Annapurna Landscape (CHAL This paper discusses the impact of climate change impact on livelihoods and how those climate risks are minimized in order to improve forest based livelihood through adaptation planning.

\section{MATERIALS AND METHODS}

Study sites

The study area for this research is Chitwan Annapurna landscape. The 
Chitwan-Annapurna Landscape (CHAL), a North-South linkage includes whole or part of 19 districts of the Gandaki river basin drained by six major rivers covering four physiographic zones, namely the Siwaliks (including small areas of flat lands in Chitwan and Nawalparasi districts), Middle Mountains, High Mountains, and High Himal (including the trans-Himalayan region). ChitwanAnnapurna Landscape had a total of 1.14 million hectares (35.5\% of the landscape area) of forest in 2010. Hariyo Ban Program is being implemented by four consortiums. CARE Nepal has been leading climate change adaptation component. Integrated climate vulnerability and capacity assessment (ICVCA) is being piloted and prepared community based integrated climate change adaptation plans of action targeting poor, vulnerable and socially excluded people in different location of three river system (Seti, Marsyangdi and Daraundi) of Kaski, Syangja, Tanahu, Lamjung and Gorkha. People residing in this region are poor and highly dependent on fragile sensitive natural resources, especially forest for their livelihoods. This whole Chitwan Annapurna area is very potential for high valued biodiversity and is the habitat of about 4.5 million people (CHAL Rapid Assessment Report, 2012). Many of these people are poor, marginalized and socially excluded. The livelihoods heavily rely on forests and subsistence agriculture. Many parts of CHAL areas are under continued human pressure and critical due to high dependency on natural resources, prevalence of high degree of soil erosion as well as land degradation from various anthropogenic activities. Consequently, many people and ecosystems are highly vulnerable to the adverse impacts of climate change.

\section{Tools and Process}

Hariyo Ban Program has piloted Integrated Community and Ecosystem Vulnerability Assessment and adaptation planning. The assessment ad planning process is strengthened with tools from various vulnerability assessment tools from CARE, WWF and other organizations (CVCA (Climate Vulnerability and Capacity Assessment handbook, WWF's Flowing Forward approach as well as GON's Local Adaptation Plan of Action). This integrated process recognizes the importance of both principles of human rights and ecosystem conservation which are closely interlinked each other. Helping vulnerable people and restoring ecosystem services are the core themes of this integrated tool and thus helps to build the resilience of both ecosystem and vulnerable human communities (Hariyo Ban Program, 2012). This tool embraced the participatory methods and techniques which are presented in the following framework (Figure 1)

The first steps of identifying vulnerable site include the process of classification using tools of underlying causes of poverty and vulnerability assessment (UCPVA). In this assessment, various social tools like Power map, hazard map, poverty ranking etc are used. All the wards from VDC are ranked and the most vulnerable and marginalized sites are selected for the detail vulnerability assessment. Various preparatory works are done and series of steps are followed for assessing community and ecosystem vulnerability, adaptation planning and monitoring 4 . 
Focus group discussions (FGD) were conducted to collect more qualitative information on people's livelihood and gender and social exclusion issues. The respondent were the members of CFUGs, executive members of respective 22 CFUGs, as well as government officials like VDC secretary, Junior Agriculture technician, health workers etc.

Figure 1: Process of Integrated Community and Ecosystem Vulnerability Assessment and Community Adaptation Plan of Action (CAPA) - Guidance Manual, Hariyo Ban (2013)

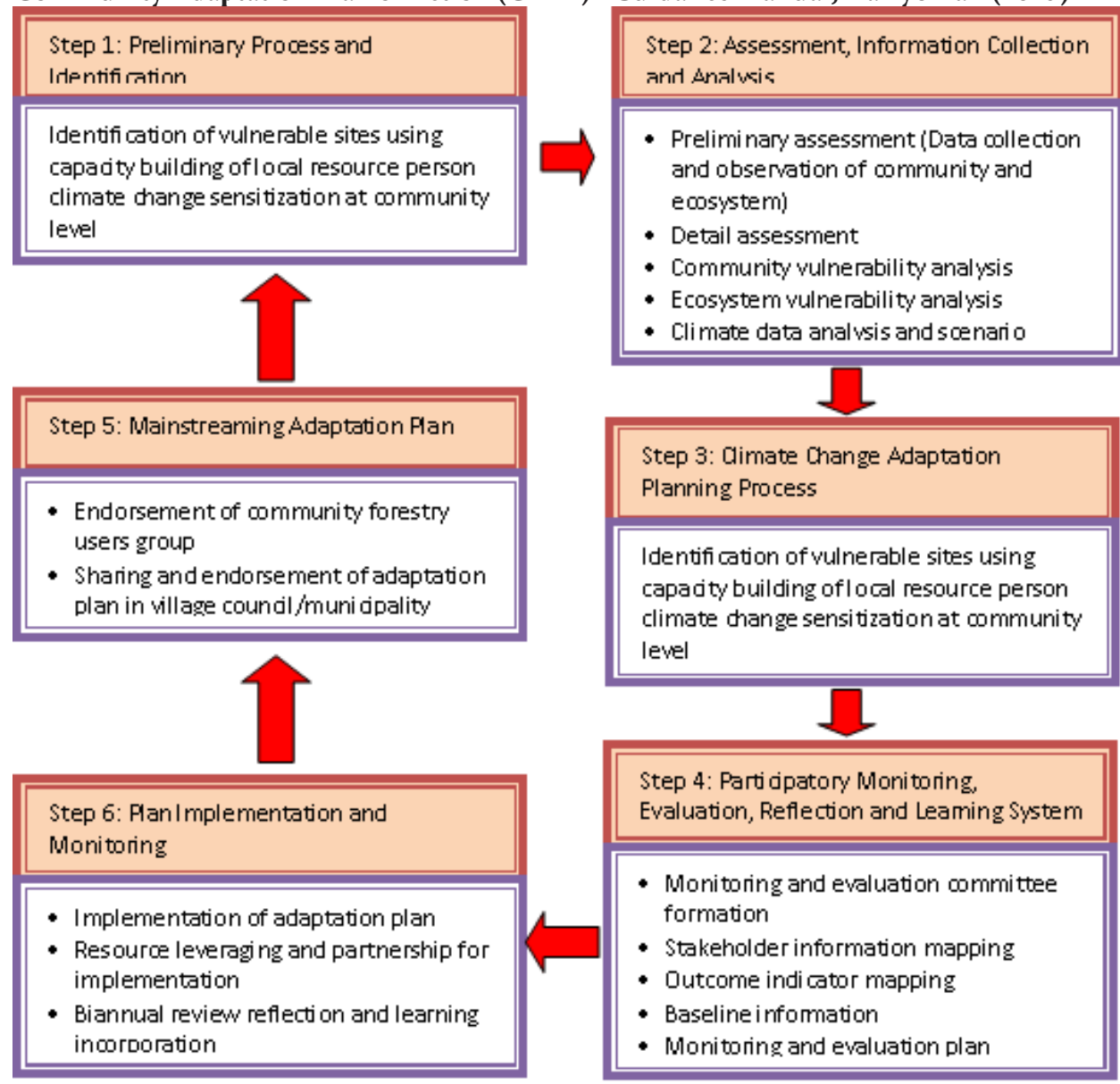

Various community vulnerability and ecosystem vulnerability assessment is made using participatory rural appraisal tools. Vulnerability assessment and community based adaptation plan is prepared after 4 days of consultative processes. Ecosystem vulnerability is measured in three different types of ecosystem i.e. forest, agriculture and aquatic ecosystems. The vulnerability assessments in the ecosystem are made on the basis of participatory ranking in different aspects of ecosystem from the climatic stress. For example, forest ecosystem vulnerability assessment; impacts of different climatic and non climatic stress was assessed in terms of 5 different indicators like, change in plant species, change in wild-animal species, forest quality/health, condition of forest connectivity and change in ecosystem services from forest. The score 
of 1, 2 and 3 was provided based community experience on the nature of impacts of different stress and/or disaster - low, medium and high respectively.

\section{Data Analysis}

In this paper, the information collected from 22 CFUGs in group in five districts (Kaski-5, Tanahu-5, Gorkha-5, Lamjung-5 and Syangja-2). The total households covered in these CFUGs were 3054, out of which $44 \%$ were vulnerable households from different climatic stressors like water stress, fire, landslide and flood.

\section{Results}

The result revealed that various climatic and non climatic stresses have stimulated and had different impacts in community and ecosystem, which ultimately impacts the forest based livelihood. The following forest based livelihoods were observed in the selected CFUGs:

- NTFPs management: cultivation, collection and selling

- Timber and fuel wood collection and selling

- Fodder, forage

- Livestock raising

- Agriculture, farming cash crops

- Forest based Entrepreneurship (Sawmill, furniture shops)

- Off-farm

- Remittances and in addition Interlinked relationship between NR and Agriculture and Animal Husbandry

Nine different climatic stresses were observed in the communities under this study. They are: Invasive Species, Landslide, Forest Fire, Drought, Flood, Pest and Diseases, Windstorm, Hailstorm and thunderstorm. Non Climatic Stress are illegal poaching/logging, Encroachment, Grazing and Red Ants.

These climatic and non climatic stresses affected the livelihood options of the people in the area, 9 different climatic stresses and 4 different non climatic stresses reported from 22 communities in mid hills of Nepal (Table 1).

Table 1: Occurrence of climatic and non climatic stresses observed

\begin{tabular}{|l|l|l|l|}
\hline \multicolumn{1}{|c|}{ Climatic Stress } & \multicolumn{1}{|c|}{$\begin{array}{c}\text { Occurrence reported } \\
\text { in CFUGs }\end{array}$} & \multicolumn{1}{|c|}{ Non Climatic Stress } & $\begin{array}{c}\text { Occurrence reported } \\
\text { in CFUGs }\end{array}$ \\
\hline Invasive Species & $91 \%$ & Illegal poaching/logging & $36 \%$ \\
\hline Landslide & $86 \%$ & Encroachment & $18 \%$ \\
\hline Forest Fire & $82 \%$ & Grazing & $4 \%$ \\
\hline Drought & $77 \%$ & Red Ants & $2 \%$ \\
\hline Flood & $54.5 \%$ & & \\
\hline Pest and Diseases & $50 \%$ & & \\
\hline Windstorm & $45 \%$ & & \\
\hline Hailstorm & $13 \%$ & & \\
\hline Thunderstorm & $2 \%$ & & \\
\hline Source: Field Survey, 2012. & & \\
\hline
\end{tabular}




\section{Crossing the Border: International Journal of Interdisciplinary Studies}

Table 1 shows, the highest occurrence of invasive species is growing creating problem everywhere. As shown in the Table 1, the invasive species are the major threat to the ecosystem services like forest like fuel wood, fodder, NTFPs. The major invasive species found in the area are Lantana camar and, Ageratina adenophora. The vulnerability assessment also showed the occurrence of invasive species in forest as well as in agriculture land. Landslide and fire are the other most prevailing climatic stress affecting the forest based livelihoods. Water scarcity due to increasing temperature has lead into drought affecting the plants and animal species and 77\% CFUGs are facing problem drought. The new emerging stresses like pest and diseases, windstorm, hailstorm and thunderstorms also damage the forest products. Hailstorm and windstorm events are increasing and are occurred after long term in many places and have severe impacts. Many birds and wild animals are killed by hailstorms and many trees are fallen from the strong wind. Similarly, non climatic stresses like illegal poaching/logging, encroachment of forest land, grazing and increasing red ants are also taken as non climatic risk which indirectly related to the impacts of climate change.

The community perception on the impacts of climate and non climate impacts on livelihood are expressed in terms of assets: Natural, Physical, Financial, Human and Social.

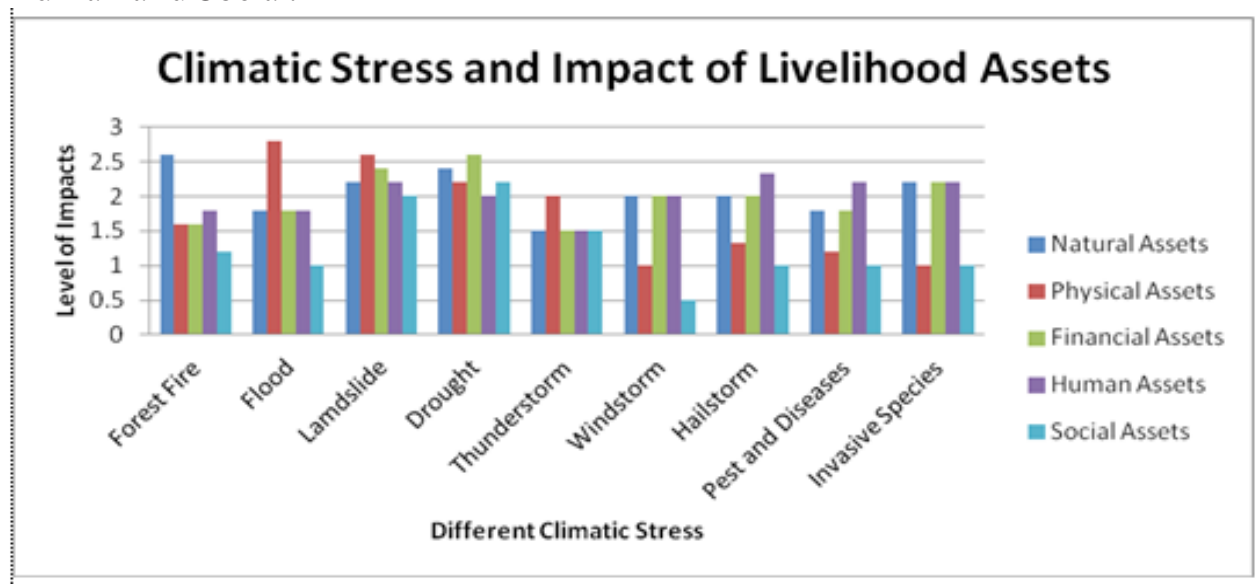

Figure 2: Climatic Stress in different livelihood assets

The graph shows that the natural assets are mostly affected by all types of climatic stress and the physical assets are impacted by disaster like flood, landslide. The five livelihood assets and some examples reported during the interaction with the communities are as follows:

In general, natural assets are affected differently by various climatic stresses. Forest fire is in the top in terms of its effect on natural asset. In some places, the emerging climate induced events like hailstorm are seen after long gap like in Lamjung and Gorkha, where community people have reported unexpected events. Though such event are of very short period, it has huge impacts and it destroys the flowering, fruiting, which ultimately hamper the product of the season.

Physical assets like schools building, community and cooperative building, 
water reservoir tanks and taps, rural village roads, ponds, bridges are mostly affected by floods and landslide. Drought affects mainly the water reservoirs tank and taps with prolonged dryness, destroys pond structure Incidence of thunderbolts are also increasing causing problem to houses, livestock's and peoples life. Community people have also linked the increasing incidence of thunderbolts with the telecom towers residing in their village which wavelength are attracting thunderbolts in Kaski and Tanahu. Floods often destroy the local village bridges every year and village roads making transportation difficult during the whole monsoon season. Women have to travel far for fodder collection and fetching water sources.

Financial assets like small business, NTFPs selling, fuel wood and fodder collection and selling, cooperatives, remittances, agriculture etc. are also affected at various levels. The declines in production of NTFPs have reduced the income of NTFP businessman and the revenue for the CFUGs.

Human assets like forest guards, carpenters, farmers etc are also affected by various climatic stresses. Forest guards and forest users have to spend their lot of time in controlling forest fire. Especially women collecting fodder and livestock grazing are in fear due to fire and they lost their conscious due to nervousness from fire. Flashflood is risk for inundation of settlements as well as damages of agriculture land and loss of life. Flood and landslide also hamper the school children.

Social assets like community forest users group committee, schools development committee, temples, youth clubs, and cooperatives also affected by various events due to which they have to change their regular settings, postpone the meetings, sometime make conflict due to resource and workload for forest management, fire control and clearance for invasive species.

\section{FOREST ECOSYSTEM AND CLIMATIC STRESS}

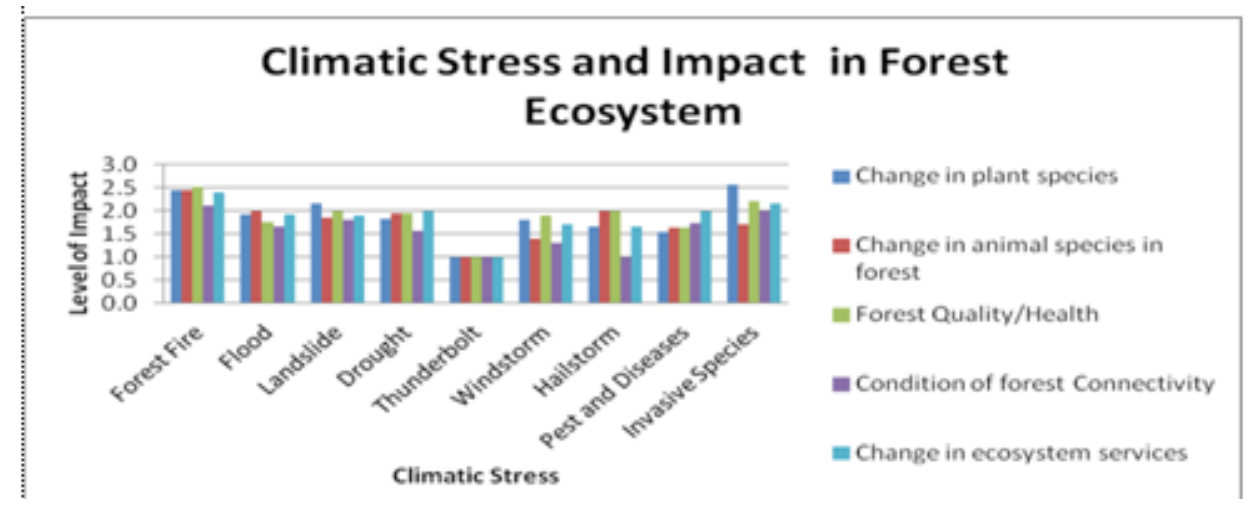

Figure 3: Climatic Stress in Forest Ecosystem

Various climatic stresses affect different aspects and characteristics of the forest ecosystem. A specific event can have significant impact on the floral, faunal species, forest connectivity, alters ecosystem services and degrades the forest ecosystem. The graph in figure 3 clearly depict the stresses of different hazards utter the dif- 


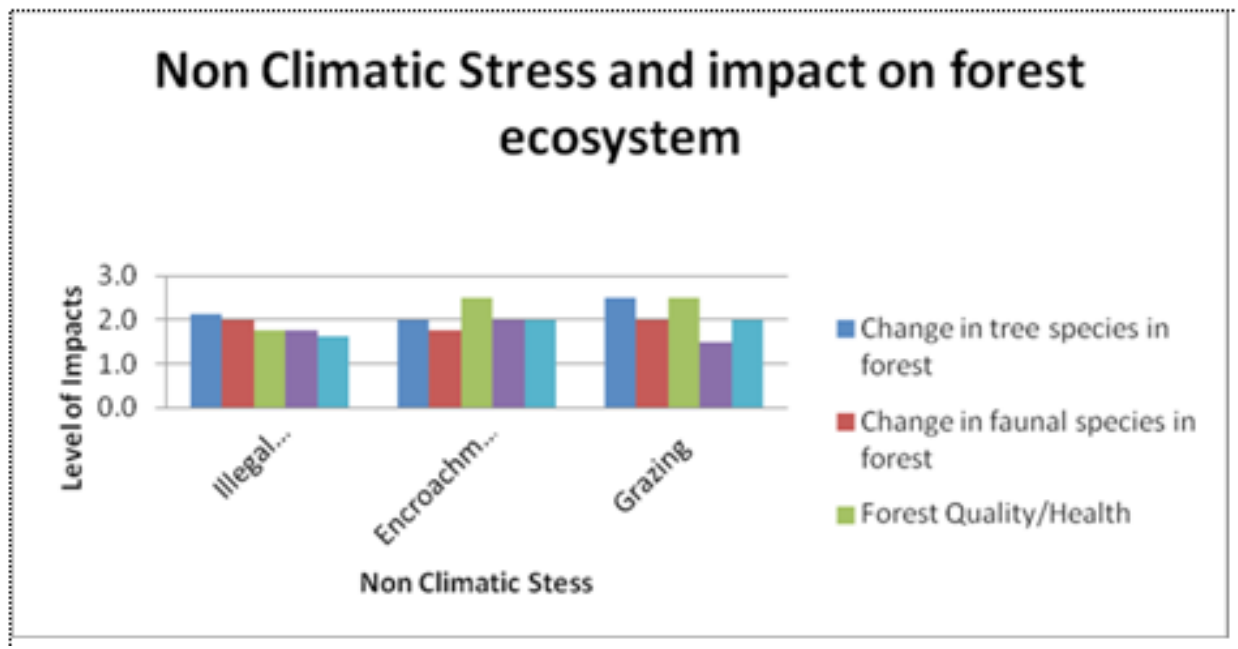

Figure 4: Climatic and Non Climatic Stresses in Forest Ecosystem

ferent indicators of the forest ecosystem. Annual forest fire is the most precedent climatic stress which has seriously impacts on all five aspects of forest ecosystem. Invasive species shows the impact above the average level in all aspects besides the showing slightly low impact in change in faunal species. All other stresses have an average level of impact in forest ecosystem. Likewise, non climatic stresses like illegal harvesting, encroachment and grazing also have serious impacts forest ecosystem which will ultimate drive the consequences of the climate change in the long run. Community forest users have different anecdotes related to the changing forest based livelihoods from the climate change. Pest and diseases has severely affected leafs, wood and degraded forest quality. People shares earlier the villagers used to make leaf plates for parties, worshiping in different ceremonies like wedding, mourn, festivals etc and people forced to use plastic plates which will pollute the environment and ultimate increase the green house gases. The hailstorms have killed several birds and wild animals. Floods and landslide have washed out the hectares of forest lands. These all climatic and non climatic stressed have seriously reduced the livelihood options of forest based communities.

\section{ADAPTATION FOR IMPROVING FOREST BASED LIVELIHOOD}

The majority of the adaptation options identified forestry and biodiversity sector besides the other five priority sectors identified by national adaptation plan of action (NAPA) in 22 different community based climate change adaptation plan of actions are shown in Table 2.

Table 2: Adaptation Activities and its Contribution toward increasing Adaptive Capacity

\begin{tabular}{|l|l|}
\hline $\begin{array}{c}\text { How to address the climatic and non climatic } \\
\text { stress through adaptation plan? }\end{array}$ & \multicolumn{1}{c|}{ How will it help to enhance livelihood? } \\
\hline $\begin{array}{l}\text { Fire fighting training, awareness and fire line } \\
\text { construction. }\end{array}$ & $\begin{array}{l}\text { Trained manpower for fire control and commu- } \\
\text { nity capacity enhancement. }\end{array}$ \\
\hline Water Source Protection & $\begin{array}{l}\text { Maintains moisture in forest and supplies drink- } \\
\text { ing water to communities. }\end{array}$ \\
\hline
\end{tabular}




\begin{tabular}{|l|l|}
\hline $\begin{array}{l}\text { Landslide mitigation through green dyke, } \\
\text { plantation of fodder species like stylo }\end{array}$ & $\begin{array}{l}\text { Stabilizes soil, maintains forest and provides } \\
\text { livelihood for community. }\end{array}$ \\
\hline $\begin{array}{l}\text { Plantation of new varieties of grasses in bar- } \\
\text { ren land and landslide area }\end{array}$ & $\begin{array}{l}\text { Maintains greenery and provides livelihood op- } \\
\text { tion. }\end{array}$ \\
\hline Clearance of invasive species before flowering. & Regeneration of tree species and grass species. \\
\hline Composting of invasive species & $\begin{array}{l}\text { Supports to restore forest and green manure in } \\
\text { agriculture. }\end{array}$ \\
\hline Installation of improved cook stoves. & $\begin{array}{l}\text { Reduces forest pressure, adapt with less firewood } \\
\text { availability and emission mitigation. }\end{array}$ \\
\hline $\begin{array}{l}\text { Support poor and marginalized households } \\
\text { through leasehold forest within community } \\
\text { forest }\end{array}$ & $\begin{array}{l}\text { Restores degraded forest area and supports liveli- } \\
\text { hood of poor and marginalized. }\end{array}$ \\
\hline Green Enterprises. & $\begin{array}{l}\text { Sustainable harvesting of forest products and } \\
\text { alternate livelihood option. }\end{array}$ \\
\hline Livestock Resource Centre Establishment. & $\begin{array}{l}\text { Promotes forage plantation and Improves liveli- } \\
\text { hood and control grazing. }\end{array}$ \\
\hline $\begin{array}{l}\text { Bamboo and broom grass plantation for in- } \\
\text { come generation for poor and marginalized. }\end{array}$ & Income generation, land restoration. \\
\hline $\begin{array}{l}\text { NTFP productions like Chiraito, Cardamom } \\
\text { etc. }\end{array}$ & $\begin{array}{l}\text { Income generation activity for livelihood im- } \\
\text { provement. }\end{array}$ \\
\hline Fruits farming (Banana, Papaya etc). & Livelihood Improvement. \\
\hline Climate change awareness to herders. & $\begin{array}{l}\text { Protects rangeland ecosystem and management of } \\
\text { highland NTFPs. }\end{array}$ \\
\hline Skill based training for firewood seller. & Conserves forest and alternate live hood option. \\
\hline $\begin{array}{l}\text { Anti poaching unit formation and aware- } \\
\text { ness campaign. }\end{array}$ & Control illegal poaching and encroachment. \\
\hline
\end{tabular}

Implementation of adaptation activities at the grassroots level through community forest users groups have change the thinking perception of community people in managing their forest in integrated way and has enhanced the capacity of executive members of CFUGs and also broaden the earlier way of forest management style. Previously before the climate vulnerability assessment and adaptation plan preparation and implementation in community forest users groups, the majority of the work only focuses to forest product harvesting, its use, block management etc. But, in recent context of implementation of adaptation plan, community forest management are interlinked with livelihood, reducing the vulnerabilities and enhancing the resilience capacity of forest ecosystem as well as community through integrated management of forest, water, energy, biodiversity, climate induced disaster, agriculture and livestock raising etc.

\section{DISCUSSION}

Hairyo Ban program has enhanced the knowledge and skills of the forest dependent communities through awareness, sensitization and trainings on climate change during vulnerability assessment, adaptation plan preparation and implementation of the plan. Awareness of climate change adaptation in communities are gaining momentum and forest ecosystem and forest dependent communities 


\section{Crossing the Border: International Journal of Interdisciplinary Studies}

and their livelihoods are vulnerable to climate change as well as the vulnerability of forests will lead to the vulnerability of the people (Gupta 2011).

Community based integrated adaptation plan of action had enhanced the capacity of forest based livelihood community to build their resilience. Enhancing forest based livelihood options with different adaptation activities has supplemented to increasing natural assets. There is no doubt that integration of ecological and social approach for adaptation helps to increase improve forest based livelihood. The ultra poor people of remote, vulnerable and marginalized communities are aware of the changing climate and the effects to their fewer livelihoods option which are further in threat. The changing pattern of precipitation and temperature resulting into various problem like erratic and unusual shifting in rainfall, increasing hailstone, fog, less availability of water, increasing invasive species, emerging pest and diseases, uncertain flashflood, and landslide have triggered the sources of their livelihood. The most changed impact of climate change is pest and diseases in, forest species, agricultural crops, livestock's raising, and their health.

Identifying the vulnerability to their livelihood options, the poor have developed community based adaptation for climate change. The plans that can be done by community people and with less resource are being implemented. However, for large plans which require technical support and other resources (financial) they require support from district line agencies; with local people, civil society, government office and other organizations. It necessitates support from individuals and groups that have little experience of such processes and few resources to draw on for implementation of community based adaptation plans.

CFUGs could play an important role in addressing issues of climate justice, tenure and property right issues (who owns carbon), equity and inclusion (how the benefits could reach to the poorest of the poor) through piloting and developing mechanism and modality (CARE 2009). Despite of the regular operation plan of community forest users groups, the community based integrated climate change adaptation plan of the respective community forest will ensure the preparedness and mitigation action towards various hazards occurring though climatic and non climatic stresses and building the resilience capacity of ecosystem as well as community people. This has also hanged the management perception of community forest linking with scientific forest management and act with future climate scenarios. Community people are no different though they are affiliated to CFUGs, farmers groups, mothers groups, water users committee etc, and integrated plan will help to widen the thinking capacity in terms of risk reduction and take more ownership toward the implementation of the adaptation planning. Implementation of adaptation plan covering an integrated actions in 6 different priority sectors of community based integrated climate change adaptation plan of action will improve the forest health and so do the forest based livelihood. CHAL study report has mentioned community based forest management are successful in forest restoration in conservation, and in addition further efforts should be made to ensure rights of local and indigenous communities to protect and enhance their forest-based livelihoods through actions suggested of protecting the rights, providing alternative energy, promoting NTFP-based forest enterprises and tourism, and 
increasing access of remote communities to education, health services, electricity, drinking water, and communications technologies (WWF, 2012).

\section{CONCLUSION}

Forest based livelihood are at the verge of destruction not only from different climatic, but also from non climatic risk and requires immediate serious action for protection of communities, ecosystem which are threatened by devastating impacts from fires, floods, landslide, pest and diseases, drought, avalanches, encroachment, and grazing etc. Community forest user group's committee at the grassroots level could enhance the forest health and condition through integrated adaptation planning to conserve forest ecosystem and ensure human rights for its sustainable use through implementation of multi-sectoral activities besides forestry. This will help diversify and sustain the livelihoods options of forest dependent communities including poor.

The application of integrated approach for adaptation planning piloted and tested by Hariyo Ban Program will contribute to fulfill the gap in the existing policy instruments for integrated climate change adaptation plan of action at the community level. These initiatives also support the structure of Local Adaptation Plan of Action (LAPA) which has mentioned about the ward/hamlet level adaptation plan at the bottom. It is hoped that this approach of Hariyo Ban program will enhance in developing the adaptation plan in different districts and contribute the main goal of NAPA of mainstreaming climate change in development agenda.

\section{ACKNOWLEDGEMENTS}

This paper is made possible by generous support of American people through the United States Agency for International Development (USAID). The contents are responsible to CARE Nepal and do not ne3cessarily reflect the views of USAID or the United States Government.

\section{NOTES}

1. http://climateadaptation.tumblr.com/post/47503707371/first-world-climate-conference-was-held-in-1979

2. http://maplecroft.com/about/news/ccvi_2013.html

3. The Hariyo Ban is a five-year USAID funded program commenced from August 2011. Overall goal of Hariyo Ban program is to reduce adverse impacts of climate change and threats to biodiversity in Nepal. Hariyo Ban program is implemented in two important landscapes: Terai Arc Landscape (TAL) stretched between the Bagmati River in the east and Mahakali in the west including Churia range, and north-south Chitwan-Annapurna Landscape (CHAL) encompassing Kali, Seti, Marsyangdi and Trishuli river basins. The program is implemented by four consortium partners WWF Nepal, CARE Nepal, FECOFUN and NTNC.

4. CARE (2012) Hariyo Ban Program, Integrated Community Adaptation plan of Action Handbook.

\section{REFERENCES}

CARE 2009. Climate Change Impacts on Livelihoods of Poor and Vulnerable Communities and Biodiversity Conservation. A Case Study in Banke, Bardia, Dhading and Rasuwa Districts of Nepal. SAGUN Program.http://www.careclimatechange.org/files/ 


\section{Crossing the Border: International Journal of Interdisciplinary Studies}

reports/Nepal_CC_Study.pdf

CARE 2009. Climate Vulnerability and Capacity Assessment Handbook. CARE International (http://www.careclimatechange.org/cvca/CARE_CVCAHandbook.pdf)

CBS. 1999. Statistical year book of Nepal. Central Bureau of Statistics, Kathmandu.

Ghimire, R.P. 1999. Biomass based co-generation in Nepalese industries: Potential and impediments. WECS Bulletin, 10(1 and 2). Water Energy Commission Secretariat, Kathmandu.

GoN, 2010. National Adaptation Programme of Action (NAPA) to Climate Change. Ministry of Environment, Nepal.

Gupta, S.P, 2011. Climate Change, Forest Resource and Risk of Violent Conflict in Nepal: Understanding the Linkage. Term Paper Report on "Conflict and Natural Resource System Management” http://www.forestrynepal.org/images/publications/CC, \%20 FR\%20and\%20Conflict.pdf

Info Resources, 2004. Climate Change and Forest Based Livelihood. Focus No. 2/04.

Reid, H. and Huq, S. 2007: How we are set to cope with the impacts. Adaptation to Climate Change. International Institute for Environment and Development (IIED) Briefing. WWF 2010. Flowing Forward. (http://www.flowingforward.org/pdf/full.pdf)

WWF, 2012. Drivers of deforestation and forest degradation in Chitwan-Annapurna Landscape. Hariyo Ban Program. (Unpublished).

\section{ABOUT THE AUTHOR}

Pratima Shrestha, a master's degree in Environmental Science from Tribhuvan University, is working as Climate Change Adaptation Specialist for Chitwan Annapurna Landscape (CHAL) in Hariyo Ban program, CARE International Nepal since October 2011. She leads capacity building, preparation and implementing the climate change adaptation at community and local level, mainstreaming adaptation plan into local development plan, participatory monitoring evaluation reflection and learning (PMERL) etc. Previously she was engaged with CARE Nepal in Churiya Livelihood Improvement Program (CHULI) at the capacity of DRR officer as well as DRR and CC specialist. Prior to this, Ms. Shrestha has extensive work experience as Project Officer in Building Disaster Resilient Communities in Nepal under Disaster Preparedness in ActionAid Nepal; Team member in the Survey of Otter in Seep Water Nepal; Faculty member in Patan Multiple Campus; Editor in e-newsletter "Headlines Himalaya" in Environmental Graduates of Himalaya (EGH); Consultant for Community Based Integrated Natural Resource Management Project in IWMI (International Water Management Institute) Nepal; Program Assistant in conservation education projects in NATURE; Field Interviewer in different researches related to Women and Child Health in New ERA Ltd. Email: pratima@ np.care.org

Dev Raj Gautam is working as Team Leader in Hariyo Ban Program, CARE Nepal. He has more than 13 years of working experiences in Biodiversity Conservation, Ecosystem and Community Based Climate Change Adaptation, Payment for Ecosystem Services and REDD+. He also possesses expertise on Participatory Forest Management and Strategic Planning, Carbon Stock Assessment, NRM Governance, Policy Analysis and Advocacy, Right-based Approach to Development, and Monitoring and Evaluation. He has already published number of articles and reports related to rights to development, gender empowerment, biodiversity conservation, climate change adaptation, community forestry management, participatory impact monitoring in national level journals and bulletins. 